\title{
Community-based Prevention of Radicalism: Psychosocial Perspective of Radicalism in Indonesia
}

\author{
Rindha Widyaningsih ${ }^{1}$, Kuntarto $^{2}$, Muhamad Riza Chamadi ${ }^{3}$ \\ \{reindha_84@yahoo.co.id ${ }^{1}$, kuntarto_bobosan@yahoo.com ${ }^{2}$,riza.chamadi@gmail.com ${ }^{3}$ \} \\ 1,2,3 Jenderal Soedirman University, Purwokerto Indonesia
}

\begin{abstract}
The social culture of the community and the carefulness in utilizing the natural potential possessed contribute to the success of radicalism prevention strategies. This article tries to answer questions about the factors that shape radicalism in Indonesia, the psychosocial perspective of radicalism in Indonesia, and the prevention of communitybased radicalism. The study was conducted based on the conditions of the Indonesian people. The research design was qualitative descriptive using a phenomenological approach. The results of this study show that radicalism arises from a combination of individual internal conditions that are reinforced by external conditions. External conditions can create a diverse self-defence mechanism. Individual reactions to unfavourable external conditions create frustration that results in aggression. Prevention of community-based radicalism offers an alternative solution by utilizing the sociocultural conditions of Indonesian people starting from the family environment, educational institutions and communities.
\end{abstract}

Keywords. Community based; Radicalism; Social Psychology; Social Support

\section{Introduction}

Radicalism is one of the biggest humanity problems in the world. The radicalism turmoil in the postmodernism era stems from the many cults of dominant world ideologies such as capitalim, liberalsism or feminism born from the women's movement in the 1960s [1]. From this cult emerged the attitude of radix, which made an ideology, which was initially an antithesis of various social problems, transformed into an exclusive ideology in the form of relative truth claims. This pattern then entered the most critical ideology in the world, namely religion. Religious radicalism is a product of the interpretation of sacred religious texts using a fundamentalist approach which tends to have motions of hostility and violence more significant than the substance of religious peace itself.

Every country carries out various efforts and allocates significant funds for preventive and repressive measures against the issue of radicalism. Efforts to prevent radicalism require strategies that are always required to be innovative because patterns of movement, patterns of distribution and methods of radical movements are always metamorphosed and adaptive to the development of science and technology [2]. The sophistication of science and technology, especially in information technology, leads to a method of spreading radical ideology quickly, massive, practical and low-cost. The internet has become a strategic media for radical groups in carrying out the process of disseminating ideology, recruiting members to guide to carry out acts of extremism. 
Preventing of radical ideologies in Indonesia are handled by several institutions and ministries. The National Counter Terrorism Agency (BNPT) is the leading sector that has the authority to develop terrorism prevention policies and strategies. The three policies cover the fields of prevention, protection and deradicalization, the field of enforcement and capacity building, and the field of international cooperation [3]. Institutions that are authorized to deal with radicalism and terrorism crimes are the police, through repressive handling. However, besides taking action against cases of radicalism and terrorism, the police also have a community guidance division that has a preventive program for the dissemination of radical ideologies to the public. Institutions that have a significant role in preventing the spread of radicalism through cyberspace are the Ministry of communication and information. One of the strategies to prevent the spread of radical ideologies in cyberspace is by conducting cyber patrols by blocking sites that are indicated to spread radical content and propaganda of violence and extreme actions.

The strength of the institutional sector will never guarantee the success of preventing radicalism ideology, both online and offline. The geographical conditions of Indonesia as a vast archipelagic country with diverse geographical characteristics, the multicultural and multiethnic socio-cultural conditions of the Indonesian people make it impossible for the creation of a formulation of the prevention of radical ideology that is equally applicable in every region.

With a variety of unique socio-cultural characteristics, customs and supported by diverse geographical conditions, efforts to prevent the spread of radical ideology become unique in each region. The wealth of local wisdom of the community is also a differentiating element for strategies in each region [4]. At the national level, the government does have a national strategy within the framework of Indonesia's national geostrategy to prevent the spread of radical ideologies, but empirically, the implementation of each region has become very diverse. This strategy proves that the participation of the community has a significant stake in efforts to prevent and deal with radicalism.

Efforts to prevent radicalism cannot be left to the security forces or the government because of limited sources of funds, human resources, and technology [5]. The limitation of human resources and government funding sources has made the prevention of the spread of radical community-based ideologies the frontline for confronting radical ideologies that are growing and expanding. We need strong, continuous, consistent and compact synergy from various elements of government and full support from the community. This article aims to discuss the role of the community in counter-radicalization using psychosocial framework process. This article offers the idea that the community is a constant and valuable social capital to overcome problems in the life of the nation and state, one of which is the prevention of radical ideology.

This article aims to review the psychosocial process of the role of the community in counter-radicalization. This article offers the idea that the community is a constant and valuable social capital to overcome problems in the prevention of radical ideology. Each scope of science has a specific point of view to give a contribution to handling radicalism. Prevention of community-based radicalism is one of the alternatives given regarding the socio-cultural aspects of Indonesian society. The character of a communal Indonesian society still holds tight to family values, and take notice of the social relations factors and primordial ties is the main supporting factor for prevention of community-based radicalism strategy. Prevention radicalism based on a community through a psychosocial perspective is expected to complement the perspective of efforts to eradicate radicalism. 


\section{Method}

The study was conducted in Indonesia by conducting a study of the phenomenon of radicalism and the socio-cultural conditions of the Indonesian people by using the psychosocial framework. The research design used in this study is qualitative by using a phenomenological approach. This article outlines a Focus discussion on 1) Determinant factors of radicalism in Indonesia; 2) Psychosocial perspective on radicalism in Indonesia, and 3) Prevention of community-based radicalism.

\section{Result and Discussion}

\subsection{Determinant Factors of Radicalism in Indonesia: Intertwined of politics,religion and radicalism}

The emergence of radicalism in Indonesia is closely related to politics and religion. The radicalism movement has begun since Indonesia was not yet independent and became an independent country. The history of the birth of radicalism has its roots in political interests and uses religion as a propaganda tool. Disappointment over the primary setting of a more nationalist and neutral state gave birth to the disappointment of the Darul Islam / Tentara Indonesia group who wanted a state foundation based on Islamic religion as agreed before in the Jakarta Charter agreement. DI/TII has a broad base, but unfortunately, it only relies on charismatic leaders so that it is easily crushed when the leader is captured [2]. The DI/TII group seemed to disappear after a failed uprising and killed its leader, but his ideology never died.

As a new country, Indonesia is still in the stage of seeking identity as a State. Political and government instability continues to occur, which is characterized by a system of government and a constitution that alternates. The impact of the Old Order policy caused the Indonesian economy to collapse which was marked by hyperinflation to reach $650 \%$, high unemployment and sharply increasing poverty rates [6]. Indonesia began to achieve political and economic stability in the New Order era under Suharto's leadership. During the new order, Indonesia experienced rapid progress in the economic field, which was marked by the pace of development above 5\% [6]. The New Order era government policy that was open to foreign aid and supported by the oil boom in the 1970s made the Indonesian economy shot up and was able to bring massive development. The New Order era offered economic stability and easy life but had to be paid for by authoritarianism wrapped in a democracy which was full of repression against freedom of opinion and organization, especially religious organizations.

Economic stability in the New Order era was, in fact, pseudo and left a large amount of the country's debt. The masses reacted to the streets and demanded the resignation of Suharto who had been in power for seven periods. The collapse of the new order regime that came to power for 32 years had a tremendous impact on Indonesia. Indonesia seems to have been reborn as a new country after the collapse of the new order which was marked by the resignation speech of President Suharto on May 21, 1998. Through a long and challenging process and even tragedy and violence, Indonesia entered a new milestone with the birth of the reform era. The presence of reforms that are expected to bring a new dawn for Indonesia, in fact, has brought a variety of unexpected consequences and side effects. During the new order of freedom of organization and opinion, it was regulated in Article 28 of the 1945 
Constitution, but in its implementation, the government severely limited the movement of the organization and established the single principle of Pancasila in the political and organizational fields. Reformation opens channels of democracy and creates a space for expression more freely. As a result, organizations and religious movements have sprung up and brought diverse ideologies and thoughts, including radical ideologies, which have begun to find their path of existence [7]. Sociologically, some religious groups who felt marginalized during the New Order regime began to express the psychology of disappointment that had been stored for a long time against the government which was considered to have paid little attention and severely limited their movement [8].

Without the presence of the reform era, it is almost sure that hardline groups will not appear as a result of political repression in the New Order era [9]. The euphoria of democracy and the lifting of the anti-subversion law became the beginning of the rise of extremist groups utilizing Indonesia's immature reform situation. Radical groups began to express their interests by spreading hatred and intolerance by using methods of violence and terror.

The reforms brought many changes for Indonesia, both positive and negative. Indonesian people can even be said to have no awareness of radical groups and terrorists because during the New Order period the terms radicalism and terrorism were rarely known. The awareness that there was a significant threat called radicalism and terrorism emerged after the events of September 11, 2001, and continued with the tragedy of the Bali bombing in 2002.

The bombings in black September, Bali bombs, and the Afghan and European bombs also dragged Islam as a religion which later received stereotypes as radical religion. No religion teaches violence, but the image of Islam as a radical religion is painful to avoid when the perpetrators of the bombings use Islamic religious identity and symbols in acts of violence committed. The image of Islam as a radical religion is increasingly difficult to avoid after the recognition of the Bali bomb suspects that the bombing was motivated by religious motives [10]. Even in some countries, especially America, Islamophobia is unavoidable.

Contrary to the nature of modernization, which believes that the development of a modern, secular state will destroy religion, the reality states otherwise. In developing countries, such as Indonesia, economic and political development is not the same and congruent with welfare distribution. The high gap makes religion grow, not just worship. Furthermore, religion is a source of social solidarity and political resistance [11] .

The radicalism group movement is motivated by politics that reject the democratic system. Democracy and liberalism are considered as a package that delivers the people in misery, injustice, and a corrupt government. One of the antipathies with democracy is to reject the electoral system. The basis of the State is considered unable to resolve the dynamics of the problem, and the changing of state system based on religion is a must [2]. Radicalism has political goals, and religion is used as an attraction and creates emotional ties with the group to create a sense of belongingness.

The radicalism movement in its development utilized religious symbols and quoted holy verses that were not intact as the legitimacy of the movement, influenced and attracted interest in joining radical groups. For radical groups, the issue of quantity of members is essential because it will strengthen the legitimacy of the movement. Religion is a significant part of identity, which is often used to run politics in order to achieve particular interests [11]. As Huntington emphasized, primordial identities are the main factor for friction in civilization. Religion in Indonesia is a state affair, even though Indonesia is not a religious State. With a population of Muslims who reached $87.2 \%$ or around 207.2 million people per the year 2017 [2], making Islam has power and high bargaining position to influence political decisions and carry out pressures on different groups. The use of religion as an attraction gets a response 
from the Indonesian people who are culturally religious. Central dogmas infiltrated through recitation, religious lectures filled with verses from the Qur'an as legitimacy.

Two decades after the Reformation, Indonesia's political have undergone many changes. Radical groups have experienced metamorphosis with an adaptive movement pattern. Variants of radicalism are increasingly diverse. Not only moves through group mechanisms, but radicalism has also split into small cells that spread and even emerge own radicalism (lone wolf), and family radicalism [12]. Political, social, and economic deprivations in society have led to radical splinter groups. The group forms a cult, is exclusive, and adheres to a charismatic leadership pattern. Groups with such dogmas consider that anyone outside their group should be eradicated. This situation develops social conflict and interfaith violence, within the intra-religious sphere itself, even between religious communities [13].

In further progress, the awareness of the Indonesian people about radicalism has sharply increased. Radical groups can no longer openly emerge as extremist groups. Now radical groups are utilizing political constellation by carrying out infiltration of movements through practical political channels. Politics with a package of religion is very effective at creating members who are militant and have secure attachments to the group. It is this mass power that is used to exert political pressure on opponents and ultimately wants to replace the government-based religious system.

\subsection{Psychosocial Perspective of Radicalism in Indonesia}

Previous researches were showing that radicalism does not correlate with mental illness [14], although radical groups to recruit people who experience unstable emotional conditions [15]. Radicalism is not a form of psychological or psychopathological dysfunction, but a behaviour based on political motives and carried out rationally by people who feel their actions are right [16].

The psychological approach has a strategic role in explaining radical behaviour, especially those that use violence. The psychosocial approach helps answer the question of why someone is committed to radical groups and is involved in violence. The psychosocial approach becomes very relevant in explaining the process of involvement in radicalism. There is a robust psychological process that ensnares someone who embraces radicalism and even manifests in terrorism. The psychosocial perspective is also oriented to the design, implementation, and evaluation of psychosocial interventions aimed at reducing risk [17]. Psychosocial explanations contribute to complementing the wealth of perspectives for developing strategies for preventing radicalism.

The psychosocial approach views the emergence of a behaviour as a combination of the influence of individual psychology (individual differences) on environmental factors [15]. Radicalism arises from the combination of individual internal conditions which are strengthened by external conditions. External conditions can create a diverse self-defence mechanism. Individual reactions to uncomfortable and less benefit from external conditions are very different between individuals. The reaction could be self-destructive depression or lead to frustration that triggering aggression.

The case of radicalism in Indonesia in the last few decades is almost entirely religious radicalism. Radical groups use religion as an ideological justification and use sacred verses that are not intact as a basis for extreme actions as a manifestation of radical ideology. Radicalism, under the pretext of religion, has succeeded in attracting attention so that it has many loyal followers. Religion is a powerful magnet for the attraction of radical movements. Religion is considered capable of giving a clear and straightforward solution to all problems 
faced in the world. Religion can present persuasive and hypnotize language with afterlife happiness. At a further level, the brainwash of radicalism will foster a strong belief that radical ideology is the only solution following religious teachings. This brainwash can be seen in the case of suicide bombers who consider the bombing to be a "jihad" to get heaven [16].

Contrary to popular belief that believes that radicalism is a product of poverty, various forms of brainwashing, youth, ignorance or lack of education, lack of work, lack of social responsibility, crime, or mental illness. Marc Sageman found that friendship and family factors dominated young people more involved in extreme radicalism (Sageman, 2008). Psychological needs provide more encouragement for individuals to join radical groups, such as the discovery of identity, group conformity, purpose, and fulfilment of security [14]. Such psychological needs when meeting propaganda with a pack of religion as legitimacy will lead to the understanding that radicalism is a form of "jihad" that can satisfy psychological needs.

Internal factors as the emergence of radicalism in a person are mental health problems. Mental health conditions are closely related to happiness and boredom. Economic conditions that are burdensome and cause entanglement, systemic injustice, social inequality, poverty, disappointment, neglect, unhappy social and family relations create frustration. Frustration will lead to aggression, violence, resistance and rebellion as expressions of hurt and revenge.

Radical ideology actively targets young people because it is most easily psychologically attacked. Storm and stress period and unstable mental conditions cause young people vulnerable to the ideology of radicalism [18]. In many cases found in Indonesia, radical ideological inflations are quite massive for young people through educational institutions [19]. Radicalism has infiltrated the world of education through literature and extracurricular activities [20]. Books on the dictates of Islamic Education are often the entrance to the spread of radical ideas in schools. Many materials encourage students to be intolerant towards other groups. Besides, teachers often approve teaching materials in the book without more in-depth consideration. This condition is related to Indonesia's political after the reform, which was very open and permissive towards the birth of organizations that brought a variety of ideologies, including radical ideology. Through religious extracurricular activities, radical organizations are beginning to approach and attract the attention of the younger generation to join. Consistently, radicalism is instilled in the subconscious, children who are in the process of seeking identity. This strategy is beneficial, but it takes a long time to produce action. The result is that 10 to 15 years later, various religious backgrounds can be easily encountered in various homelands. This action is not an action that takes place overnight. There is a long and massive process, but it has never been realized because Indonesia is preoccupied with postreform political and economic arrangements.

External factors in the form of economic conditions contribute significantly to the emergence of a sense of social anger, which results in frustration and ends with acts of aggression. Economic factors also become a predictor for the occurrence of violence at the national level [14]. The economic gap between the rich and the poor with a very striking difference in the quality of life creates social grievances, and become a trigger for aggression. In many studies carried out in various countries, researchers found a strong relationship between economic marginalization, which causes poverty and the risk of radicalism [21]. Socio-economic jealousy encourages a person and group to launch a social protest against the life that will be lived. Protests are carried out simply, for example not going to an association, being reluctant to socialize, up to a higher stage by fighting a system that is considered unfair through the formation of an organization with fellow peers [22].

Radicalism is often an expression of frustration in dealing with social, economic, and political injustice during society, bring up to violent behaviours driven to realize desires and 
hopes. Disappointment with the authorities or the official government emergence radical actions. This action is a manifestation of dissatisfaction with the failure of government performance. Religion-based governance is the solution [23].

\subsection{Community-based Prevention of Radicalism}

Radicalism is the root of terrorism. Extremist actions that harm humans are enemies of all States. The handling of radicalism cannot be formulated through a single scientific perspective or just relying on repression by the security forces. Even military retaliation is counterproductive. Radicalism is a psychological battle, so the effective way to win psychological warfare is through psychological warfare [15].

Based on psychosocial understanding, radicalism is a combination of psychological and social conditions, so preventing radicalism should be flexible than hard approach. The Indonesian government has succeeded in proving that both the hard and soft approach so far has succeeded in preventing radicalism from growing and developing more extensively even though it does not mean lost entirely. The role of the social environment plays a massive role in the success of the Indonesian government in revealing the existence of a clandestine terrorist network and succeeding in thwarting the action plan that will be carried out [24].

The community has a significant role in the fight against radicalism, as stated in the United Nations Resolution on Global Counter-Terrorism Strategy 60/288, which was established on September 8, 2006. In the resolution, it was explained that the community was an essential part in preventing terrorism-radicalism through educational movements and based campaigns. Tolerance, peace and justice [25]. Indonesia indeed becomes an essential part of the UN resolution. Although Indonesia has not made individual ratification on counterterrorism, various efforts have been made by the government to educate the public and instil vigilance against the threat of radicalism-terrorism

Psychosocial approaches in the prevention of radicalism are strongly related to family and social environment communities, including social institutions in them. Family and social institutions have a significant role in increasing resistance to the recruitment of members of radical groups.

\section{Family Intervention}

Referring to Maslow's hierarchy of needs theory, basically, the need for love and affection is a basic need in humans. Love and attention are first gained by individuals are from family. In a family, someone learns to love and caring for each other. Less ideal for a family allows someone to get less portion of love, affection, appreciation and attention. Modernity brings changes in patterns of human relations very sharply, including patterns of communication and relationships within the family. Modern life that has many demands for artificial need causes the division of roles of breadwinners not only to the father as the head of the family. Gender equality and increasing the role of women participate in causing the division of roles in the family to be very dynamic. Parents' busyness has an impact on reduced feelings of caring. In some cases, it causes children to feel alienated, lonely, and lack attention and affection. As a result, children seek fulfilment of their social needs outside the home. This condition causes vulnerable children to be affected by destructive radical ideology.

Family is the first learning space at the beginning of the development of human life. The family has a significant role in providing an excellent and right understanding of religious teachings, teaching love, appreciation, and norms and values. The rapid flow of information that can be easily accessed but not balanced by the ability of families to provide alternative information has an impact on the shrinking of family resilience. A child can quickly get any 
information from the internet. Lack of communication treats a family lost of information filter role. The existence of the internet has become an essential part of forming thoughts, actions, behaviours, as well as the basic needs of today's human life. Intolerance, as a venue for recruitment, training, education, coaching networking members.

Some cases of radicalism, especially in the case of the lone wolf in Indonesia, show that there are internal factors that cause a person to carry out extreme radical actions because of the lack of attention and affection from the family. The low subjective well being in a person due to the lack of fulfilment of love needs (social need) becomes a trigger to carry out extremist actions to attract attention. In other cases, community or social group is an escape from a lack of love and affection. This unstable mental condition will be dangerous when someone enters a radical ideology group. In order to get recognition from the group, group conformity was created by conducting behavioural copying. They will voluntarily take radical actions so they can be accepted into groups [2].

Intervention in the family is a critical element of efforts to prevent the spread of radical ideology. The family is the first place children learn about tolerance. This value is essential to face the reality of a multiethnic, multi-religious, and even multi-perceptual outside world. Children are prepared to face differences and be able to live peacefully with all the differences. Adequate understanding and practice of tolerance can be an antidote to the seeds of fundamentalist thought that could develop into radical thinking. Learning in the family will be an antibody to deviant teachings that emphasize violence.

Intervention in the family is the primary key in preventing the spread of radical ideology. The kinship system and strong family principles will bring ownership and love among family members. Healthy family psychologically will be able to present healthy patterns of relationships and communication and capable of occupying basic human needs. The possibility of contracting radicalism virus will be low in psychologically healthy families. In addition to playing an essential role in the anti-radicalism process, the family also has a massive role in the process of deradicalization. Acceptance in the family will help accelerate the process of someone who has been influenced by radical ideology to live life as usual. Family support will foster feelings of acceptance and fulfilment of social needs.

2. Educational Interventions

Radical ideology infiltration in the school environment is an undeniable reality. Schools as educational institutions are not sterile from the influence of radical ideology that is presented through inadequate religious learning and the possibility of the existence of teachers who support radical thoughts [13], [19]. The survey of the Institute for Islamic and Peace Studies (LaKIP) in 2011 showed a radicalism trend among high school students in Jakarta (the capital city of Indonesia) and surrounding satellite cities. It was found that the support and willingness of students to engage in acts of violence have a relatively high tendency [26]. A real example of the influence of radical ideology that infiltrated through educational institutions is the Surabaya bombers involving all members of their families in suicide bombings, apparently having been exposed to radical ideology since they were in high school [12].

Radicalism requires young people who are full of energy and smart, both readily available to school students. They target young people who are smart and have a high curiosity. In schools and colleges, the ideal candidate members are so readily available. Through extracurricular activities, radical groups slowly influence children who are at the stage of seeking identity. Radicalism is packaged as a struggle to uphold a religion that is heroic and presents intense religious militancy. Coherent narratives lifted from everyday life, and the legitimacy of religious verses become a fascination for radical ideology to get followers. 
Educational institutions are challenging in facing various threats that lurk, young people - drug threats, juvenile delinquency, to the danger of radicalism. Parents and teachers may feel calm when students get closer to religion, take religious extracurricular activities because they are considered to be able to maintain morality and avoid wrong association. However, now, parents and teachers must be aware of the possibility of extreme ideology infiltration by religious students activities. Adequate supervision of child relationships, especially in religious groups becomes very crucial. Educational foundations also need to evaluate the management of religious education in the institutions under it. It also includes school spirituality activities and mentoring, especially those involving outside parties. The Ministry of Religion also needs to ensure that teacher education in religious high schools has prepared educators with the right religious understanding.

In addition to providing a concrete understanding of the facts of diversity, school or education is also important to teach tolerance. Tolerance is the primary key for a very pluralistic country like Indonesia. We are always faced with differences that cannot be replaced or avoided. Living together with very diverse conditions in all aspects of life makes the potential for substantial disputes to occur. Exclusive understanding is not relevant to life in Indonesia and is very vulnerable to causing horizontal conflict. The synergy of educational institutions, teachers and curriculum is needed to create a moderate and tolerant academic environment with a strong foundation of nationalism. This awareness of the necessary conditions is the foundation for inclusiveness that can bring tolerance, which will counteract puritan and exclusive thinking that is the forerunner of radical ideology.

3. Community Intervention

Community is defined as a collection of people who share regional geography, and those who have similar cultures and institutions [27]. Referring to Whitzman's theory of community crime prevention that tries to form a strategy for preventing community-based crime in a structured manner, community intervention in preventing the spread of radical ideology has a similar direction. Whitzman's theory emphasizes the role of "leaders" and "champions" as agents who play a role in building community crime prevention. "Leader" in the form of government, non-government, private groups such as the Police, Government, Community Organizations and Education Groups. While the concept of "champion" is an individual, who influences a community to move the community to prevent crime [28]. The interventions carried out include the following six steps: leaders have a theory to make community-based crime prevention; according to Whitzman, has six steps:

a. Developing a Partnership Around the Problem

The first crucial step is the shared understanding of the problems faced in the same perspective. Radicalism must be understood as a problem that threatens national security. Radicalism is discussed through a comprehensive perspective from various scientific fields to find the common thread. Each party is welcome to give opinions both through the perspective of the victim and those responsible for preventing radicalism. The first discourse of understanding the perspective driven by community leaders. Leaders can play a role in influencing the community. The group leader is expected to be a consensus builder on the problem at hand. The discussion is carried out are the prohibition of criticism of the person who is allowed is only a criticism of ideas, encouragement so that each group is willing to share the information they have. Finally, the encouragement to compromise should be considering.

Prevention of radicalism will become more comfortable when there is cooperation from government, non-government and private sectors. The government element consists of politicians, political parties, social worker groups and the police. Non-government groups 
consist of religious organizations, service groups, neighbourhood groups, and youth groups. The private sector can be in the form of business groups, trade, media, and private donor institutions [28]. In addition to leaders, the involvement of religious leaders and community leaders who have a cultural influence, or in the term Whitzman is referred to as a champion, is also a first step in giving understanding the issues of radicalism.

b. Diagnostic Tools and Community Consultation

The second step is to diagnose the resources in the community. At this stage, regional demographic data is collected to provide an overview of the physical condition of the community, such as population, socio-economic, employment, community structure and other vital data. At this stage, it can also be known how many newcomers or foreigners there are in an area. In many cases, radicalism, which led to extreme actions in Indonesia, was carried out by migrants who rented houses. They carry out radical action activities and planning not in their original domicile [29]. The obligation to report to newcomers to the head of the neighbourhood unit is one of the control mechanisms for foreigners for security needs.

At this stage, community members are asked to participate in reporting suspicious activities or people around them actively. Indonesia has a government organization that is tired from the national level to the level of the Neighborhood Unit as the representation of the lowest level government. Such a system makes it possible to control the community from the State in an effective way involving all members of the community. The active role of community members will increase public awareness of the potential for the spread of radical ideologies in their environment and suspicious activities that have the potential to cause security disturbances.

c. Developing Workplans Based on a Logic Framework

The third step is to create a specific, measurable, realistic and timely (SMART) framework [27]. Each member of the community is actively involved in making plans to anticipatory steps towards the possibility of infiltration of radical ideologies that may enter through foreigners, religious lectures or the influence of radical groups that come in various guises. Proper planning should be written and get approval from community members as indicated by the signing of the agreement. Proper planning must also contain indicators of success to measure the success of the program and conduct evaluations. In the planning stage, the determination of the schedule also becomes a matter that must be considered, even though it is tentative. The timeframe limiting does not have to be a strict limitation but only aims to provide data clarity. Planning must also consider the realistic conditions of the community by paying attention to the socio-cultural aspects, customs, and customs of the local community. Therefore planning step becomes very varied, and has no standard.

d. Implementation and Monitoring

In the implementation phase, the role of religious leaders and community leaders is crucial. Champions interact more with community members than leaders. Champions are also more likely to carry out functions of control and evaluation because they live together in the environment. The role of religious leaders is crucial in spreading tolerance through da'wah and guiding community members to implement religious values that are by the context of local wisdom. The influence of figures is still significant to ensure that religious values are understood to be able to be practised in community life [30]. In the Indonesian context, champions also play an essential role in strengthening socio-economic capacity that relies on the economic endeavours of local communities. Strengthening the economy is one of the critical activities referring to the explanation of the radicalism causes is a disappointment with the country's economy on a macro basis. 


\section{e. Evaluation}

The fifth step is evaluation. Evaluation is an important step to see the effectiveness of preventing radical ideologies that have been done, what are the shortcomings and what gaps should be closed. A big challenge at the evaluation stage because of changes in the trend that occur also require continuous evaluation of strategies. Evaluation is also used as a basis for developing radicalism prevention strategies, both technical and non-technical. The evaluation must be carried out periodically to keep monitoring safe conditions. Community members are expected to be able to actively participate in the evaluation phase through the contribution of constructive ideas, thoughts and criticisms.

f. Modification, Maintenance, and Mainstreaming

The pattern and strategy of radical ideology always change according to the times. The spread of radicalism, which was initially in the form of large and closed groups and characterized certain stereotypes of appearance, has begun to no longer appropriate [12]. They are divided into small cells, and life blends with the community without a partition. This kind of change requires modification of strategies that are in line with the latest trends. Maintenance is an effort to give attention and action to ensure that the strategies and programs implemented are still running well. Activities in the form of regular communication forums are a form of treatment. Leaders play a role in ensuring the community continues to play an active role in counteracting radicalism. Mainstreaming is an action taken so that the community has an awareness of radicalism. Increasing the capacity of the community to fight radicalism is a mainstreaming strategy. Indonesian people have implemented neighbourhood watch, security patrols managed by citizens, and supervision of access into the community. Mainstreaming also held by providing education and campaign on the dangers of radicalism, both formally and informally. Massive mainstreaming by enhancing the role of leaders and champions are expected to bring public awareness of radicalism.

\section{Conclusions}

There is no effective strategy and applies equally in each region. Foresight is needed in observing natural potential as an intervention in preventing radicalism. The issue of radicalism has complex root causes and unable to be described by individual branches of science. Psychological perspective tries to contribute to the idea of analyzing the problem of radicalism from individual internal factors. Radicalism is a problem faced by every country with different problem characteristics. Practical radicalism prevention strategies are related to multifactor as a determinant. The psychosocial conditions of the Indonesian people who still attach importance to kinship factors are used as one of the social capital to solve the problem of radicalism.

Community-based prevention of radicalism starts from the smallest scope, family, educational environment, and community. Family is the key to fulfilling the needs of love, learning to appreciate, tolerance and providing support so that individuals are satisfied with their psychological needs. Family support is another critical thing so that individuals do not feel alienated and able to face difficult times at the age of transition that is prone to the influence of radicalism.

A school environment is a place where a child interacts for a long time every day so that the school environment will be able to shape the character of the child. School is a place to develop tolerance and learn to adapt socially. Supervision of curriculum content and 
extracurricular activities is a step to prevent radicalism in the school environment must be considered. At the community level, the broader active participation of community members is the key to success in efforts to prevent radicalism from entering the residential environment through social control. Leaders and champions play a significant role in delivering program success from the planning stage to evaluation and mainstreaming. Mutual support from various parties is expected to be able to become a positive synergy for the renewal of strategies for preventing radicalism.

\section{References}

[1] B. Agger, Teori Sosial Kritis: Kritik, Penerapan dan Implikasinya, XI. Yogyakarta: Kreasi Wacana, 2009.

[2] R. Widyaningsih, Deteksi Dini Radikalisme. Purwokerto: Unsoed Press, 2019.

[3] B. R. Aisy, D. O. Ibrahim, K. K. H. Intang, and M. A. Tindage, "Penegakan Kontra Radikalisasi Melalui Media Sosial Oleh Pemerintah Dalam Menangkal Radikalisme," J. Huk. Magnum Opus, vol. II, no. 2, pp. 1-8, 2019.

[4] R. Widyaningsih and Kuntarto, "Local Wisdom Approach to Develop CounterRadicalization Strategy Local Wisdom Approach Radicalization Strategy to Develop Counter-," in IOP Conference Series: Earth and Environmental Science, 2019, pp. 17.

[5] P. R. Golose, Deradikalisasi Terorisme: Human Soul Approach dan Menyentuh Akar Rumput. Jakarta: YPKIK, 2010.

[6] I. B. G. Udiyana, I. gusti G. O. Pradnyana, and N. N. S. Astini, "Struktur dan Sistem Pembangunan Ekonomi Indonesia Masa Orde Baru,” Forum Manaj., vol. 6, no. 1, pp. 41-52, 2008.

[7] Fatkhuri, "Faktor Pendukung Terbentuknya Radikalisme dan Terorisme di Indonesia," no. July 2012, pp. 1-25, 2017.

[8] Suprihatiningsih, "Spiritualitas Gerakan Radikalisme Islam Di Indonesia," J. Ilmu Dakwah, vol. 32, no. 2, pp. 367-381, 2012.

[9] M. Hilmy, "Radikalisme Agama Dan Politik Demokrasi Di Indonesia Pasca-Orde Baru," MIQOT J. Ilmu-ilmu Keislam., vol. 39, no. 2, pp. 407-425, 2015.

[10] M. Subhan, "Pergeseran Orientasi Gerakan Terorisme Islam di Indonesia (Studi Terorisme tahun 200-2015)," J. Int. Relations, vol. 2, no. September 2001, pp. 59-67, 2016.

[11] F. R. Harahap, "Politik Identitas Berbasis Agama," in Konferensi Nasional Sosiologi, 2014, no. August, pp. 801-813.

[12] R. Widyaningsih and Kuntarto, "Family Suicide Bombing: A Psychological Analysis Of Contemporary Terrorism," Walisongo, vol. 26, no. 2, pp. 295-320, 2018.

[13] A. Munip, "Menangkal radikalisme agama di sekolah," J. Pendidik. Islam, vol. 1, no. 2, pp. 159-181, 2012.

[14] G. K. Dejacimo, "The psychology of terrorism and radicalization," Honor. Res. Proj., vol. 62, 2015.

[15] J. M. Post, "'When hatred is bred in the bone:' the social psychology of terrorism," Ann. N. Y. Acad. Sci., vol. 1208, no. 1, pp. 15-23, 2010.

[16] S. Kimhi, "Psychological Factors Enhancing Political Radicalism," https://www.stateofmind.it/2011/10/psychologicalsocial-factors-enhancing-politicalradicalism/, 2011. .

[17] S. Weine, J. Horgan, C. Robertson, S. Loue, A. Mohamed, and S. Noor, "Community 
and family approaches to combating the radicalization and recruitment of SomaliAmerican youth and young adults: A psychosocial perspective," Dyn. Asymmetric Confl., vol. 2, no. 3, pp. 181-200, 2010.

[18] R. Widyaningsih and Kuntarto, "Kerentanan Radikalisme Agama Di Kalangan Anak Muda," in Pengembangan Sumber Daya Perdesaan dan Kearifan Lokal Berkelanjutan VII, 2017, vol. 6, pp. 1553-1562.

[19] Moh. Hasim, "Potensi Radikalisme Di Sekolah Studi Terhadap Buku Pendidikan Agama Islam Sekolah Dasar," EDUKASI; J. Penelit. Pendidik. Agama dan Keagamaan, vol. 13, no. 2, pp. 255-268, 2015.

[20] Convei and PPIMUIN, "Brookings Policy Brief Series," 2018.

[21] A. Rink and K. Sharma, "The Determinants of Religious Radicalization: Evidence from Kenya," J. Conflict Resolut., vol. 62, no. 6, pp. 1229-1261, 2018.

[22] Z. Qodir, Radikalisme Agama Di Indonesa. Yogyakarta: Pustaka Pelajar, 2014.

[23] Kuntarto and R. Widyaningsih, "Dinamika Psikologis Pelaku Radikalisme," in Pengembangan Sumber Daya Perdesaan dan Kearifan Lokal Berkelanjutan VIII, 2018, no. November, pp. 273-282.

[24] N. Hasan, B. Hendriks, F. Janssen, and R. Meijer, Counter - Terrorism Strategies in Indonesia , Algeria and Saudi Arabia. Netherlands: Netherlands Institute of International Relations "Clingendael," 2012.

[25] S. Wahyuni, "Kontra-Radikalisme dan Terorisme Berbasiskan Masyarakat di Jawa Tengah,” BNPT Jakarta, 2017.

[26] A. Baedowi, "Paradoks Kebangsaan Siswa Kita," Maarif, vol. 8, no. 1, pp. 67-81, 2013.

[27] C. Whitzman, The Handbook Of Community Safety, Gender, And Violance. New York: Taylor \& Francis, 2008.

[28] K. H. Nugroho and D. Sudiadi, "Pencegahan Kejahatan Berbasis Komunitas Terhadap Terorisme Oleh Masyarakat Desa Cemani Kecamatan Grogol Kabupaten Sukoharjo Provinsi Jawa Tengah,” J. Fisip UI, pp. 1-17, 2014.

[29] R. Widyaningsih, S. Sumiyem, and K. Kuntarto, "The Potential of Religious Radicalism Movement in Banyumas," Walisongo J. Penelit. Sos. Keagamaan, vol. 25, no. 1, p. 203, 2017.

[30] M. Syafar, "Pemberdayaan Masyarakat Berbasis Masjid Untuk Menangkal Radikalisme Islam Di Banten,” Lembaran Masy., vol. 4, no. 2, pp. 43-63, 2018. 